\title{
A Brief Account of Abstract and Concrete Elements of Language
}

\author{
Ahmed M. S. Alduais ${ }^{1 *}$
}

\section{ABSTRACT}

Purpose: What do abstract elements of language refer to and how they can be distinguished from concrete ones is the main concern of this paper.

Method: The study is mainly descriptive where previous and related studies are reviewed and presented to reach a view about abstract and concrete elements of language.

Results: Whatever spoken and written is concrete element of language and whatever processed and acquired or learnt is abstract element of language. Linguistic elements before use are abstract and when being used they turn into concrete ones.

Conclusions: Our stored linguistic and mental abilities are to be taken as the abstract element(s) of language, yet our attempt and desire to use the stored linguistic and mental abilities and put them into actions are the concrete element(s) of language.

Keywords: Language, Abstract Elements, Concrete Elements

In language study, research and theory- a distinction is made between abstract and concrete elements of language. Strictly speaking, knowledge and its use, consciousness and unconsciousness and input and output are all used conversely and can explain the difference(s) between abstract and concrete elements of language. However, such elements are interpreted in many ways. That is, in terms of language study and theory as mentioned above they may refer to what is known as 'competence' and 'performance'. The main reason behind this interpretation is that because what is referred to as 'abstract' - 'competence' is invisible. On the other hand, 'performance' which is referred to as concrete element of language is visible. Put it another way, the former is unseen and the latter is seen. Again, one which is abstract is not testable and the other which is concrete is. Once again, it is proposed that because we cannot see what is in our minds so it is mentioned as abstract. On contrary, because our production for the language elements can be seen as spoken language and it can be judged so it is mentioned as concrete element.

In one way or another, what is known in linguistics as phonology, phonetics, morphology, syntax and semantics, etc. are to be taken/considered as language elements in general. In spite of this, the point is that when these elements are in our minds so they are referred to as abstract

\footnotetext{
${ }^{1}$ Department of Linguistics, Social Sciences Institute, Ankara University, 06100, Sihhiye, Ankara, Turkey *Corresponding Author

(c) 2015 I A Alduais; licensee IJIP. This is an Open Access Research distributed under the terms of the Creative Commons Attribution License (http://creativecommons.org/licenses/by/2.0), which permits unrestricted use, distribution, and reproduction in any Medium, provided the original work is properly cited.
} 


\section{A Brief Account of Abstract and Concrete Elements of Language}

elements. Conversely, when they are used or more accurately spoken, they are referred to as concrete elements. In spite of this, what has been mentioned as abstract and concrete elements of language could be interpreted in more than a way. That is to say, psychologically, such elements are interpreted in terms of the interrelationship between both linguistic and mental development. It is claimed that a child acquires and produces language elements as either concrete or abstract according to his/her age or mental development (epistemology theory). Recent studies would mention and argue in favor of Chomsky's ideas claiming that we are born with native grammar which is actually abstract and our social life and experiencing life would make us able to activate our native grammar and produce it, this last process is referred to as concrete element of language.

Having generally introduced these two elements, we now mention very briefly some of the conducted studies and opinions about them. In Byram's encyclopedia (2004: pp.135-136) communicating with others in the day-to-day life is considered as the ability to make what is abstract as concrete. Needless to say, he is talking about the language elements and yet language processing and language production. Similar to Byram are (K. \& H, Johnson, 1998:pp.74-5) who state that "any human language can be seen a realization in utterances of the associated abstract linguistic system”. Just like the previous opinions, (Trask, 1992:p.50) agrees to the idea that language elements or linguistic abilities which are born with us in our minds are "an abstract realization of a native speaker's knowledge of the grammar of her/his language". As a continuous flow to these opinions, (Crystal, 1997:p.283) goes on to state that what we do in our daily life or our acts of speech and communication are in one way or another concrete elements of language and to some extent these "utterances of performance will contain features irrelevant to the abstract rule system". Simply, one can infer from Crystal's idea that what our minds contain is abstract language element and what we produce is the concrete language element.

Well, with reference to Chomsky's ideas mainly his theory of transformational generative grammar (Chomsky, 1965, 1995, and 1968) one can infer the fact that what enables us to, and provides us with linguistic ability is the abstract element of language, because we cannot make a final decision on it. Yet, what makes us or enables us to produce what is stored in our minds is the concrete element of language.

Unsatisfied with such an interpretation produced with Chomsky and his followers (Richards,1992:p.155) mentions in his encyclopedia that abstract and concrete elements of language are to be interpreted and explained in relation to both linguistic and mental development and not only to linguistic development as in Chomsky's case. However, such an idea is explained and clarified more in Piaget's theory which is known as genetic epistemology, (ibid). Piaget (1936) argues that children pass through different stages before they become able to produce abstract elements of language. He (ibid) maintains that it is only when a child is seven or more s/he becomes able to produce abstract language elements. According to him before this stage, they of course produce language elements but ones which are concrete, related to real 


\section{A Brief Account of Abstract and Concrete Elements of Language}

object in life. He continues when children reach the age of eleven they become more able to deal with abstract elements of language.

In his book, (Piattelli-Palmarini, 1980) presents in details the debate between both Chomsky and Piaget. It is shown in this book how each one of them has interpreted and viewed language elements. Whereas Chomsky views abstract element as competence and concrete as part of performance, Piaget does not.

From the point of view of that semantic and pragmatic linguistic elements of language are abstract compared to the syntactic and morphological ones; (Presseisen, Goldstein \&Appel, 1978) introduces to us abstract and concrete elements of language. They maintain that whatever elements or concepts of language we can only understand or realize intellectually are abstract. Again, whatever elements we produced and we can realize physically are concrete ones. To some extent, such an opinion is similar to Piaget's idea that children who are less than eleven years are not able to deal with abstract ideas or elements of language, because their minds have not reached yet the stage of doing so.

Learning and acquiring language in both home and school, (Davies, 1982) attempts to evaluate and at the same time compare between two processes: language and its acquisition from parents, family and society, and on the other hand, language and its learning in the school. She draws a distinction between both processes by considering the former as communicative competence and the latter as academic competence. Most importantly, according to Davies whatever is spoken and written is concrete element of language and whatever is processed and acquired or learnt is abstract element of language.

Furthermore, we can mention some of the empirical studies wherein they attempt to distinguish and at the same time determine abstract and concrete elements of language. From among these studies is JinyunKe's and Holland's study (2006:p.3) who mention with reference to Pinker and Bloom that "while earlier proposals for UG were mostly concerned with syntax, dealing with a set of highly abstract principles and parameters, recently the focus has shifted to more concrete components of language, such as conceptual system, speech perception and production mechanisms". It greatly suggests that our stored knowledge or linguistic elements are abstract and our use of these stored elements is the concrete side.

One more study is conducted by Straus (2008) who attempts to apply Chomsky's theories to mathematics. He argues in favor of that "our basic model for a child learning [his/her] first language is that $[\mathrm{s} / \mathrm{he}]$ hears one sentence after another and tries to parse each sentence using one of all the 'possible' grammars'. Straus's statement implies that the possible grammars available in a child's mind are abstract elements of language as they are not exactly determined and the chosen or the used grammar in the process of parsing refers to the concrete elements of language. 


\section{CONCLUSION}

To sum up, our stored linguistic and mental abilities are to be taken as the abstract element(s) of language, yet our attempt and desire to use the stored linguistic and mental abilities and put them into actions are the concrete element(s) of language. This is of course without ignoring the psychological interpretation that in a particular stage we in general are not able to deal with abstract linguistic concepts even when we produce them we are not aware of them as abstract ones, instead we relate them to objects in the real world. More interestingly in this interpretation is that when a particular linguistic element cannot be related to a real object in our life, we fail as children to deal with it and that is why our linguistic development or competence is to a great extent related to our mental and/or cognitive development.

\section{REFERENCES}

Byram, M. (Ed.). (2004). Routledge Encyclopedia of Language Teaching and Learning. London and New York: Routledge Taylor \& Francis Group.

Chomsky, N. (1965). Aspects of the Theory of Syntax. Cambridge, MA: MIT Press.

Chomsky, N. (1968). LANGUAGE AND MIND (EnlargedEd.). New York, Chicago, San Francisco, Atlanta: Harcourt Brace Jovanovich, Inc.

Chomsky, N. (1995). The Minimalist Program. Cambridge, MA: MIT Press.

Crystal, D. (1997). A Dictionary of Linguistics and Phonetics (4th Ed.). Blackwell: Blackwell Publishing.

Davies, A. (Ed.). (1982). Language and Learning in Home and School. London, Heinemann Educational Books.

Johnson, K. (Ed.). (1998). Encyclopedic Dictionary of Applied Linguistics. Blackwell: Blackwell Publishing.

KE, J. (2006). Language Origin from an Emergentist Perspective. Applied Linguistics Journal, pp. 691-716.

Piaget, J. (1936). The Origins of Intelligence in the Child. Harmondsworth, Middlesex, England:Peguin Books.

Piattelli-Palmarini, M. (Ed.). (1980). Language and Learning: The Debate between Jean Piaget and Noam Chomsky. Cambridge, Massachusetts, Harvard University Press.

Presseisen, B. Z. (Ed.). (1978). Topics in Cognitive Development: Language and Operational Thought. New York and London, Plenum Press.

Richards, J. C. (1992). Longman Dictionary of Language Teaching and Applied Linguistics. Longman: Longman University Press.

Straus, K. J. (April 2008). Validation of a Probabilistic Model of Language Acquisition in Children. A dissertation, Doctor of Philosophy: Department of Mathematics, Northeastern University, Boston, Massachusetts (Available at http://proquest.umi.com/login).

Trask, R. L. (1992). A Dictionary of Grammatical Terms in Linguistics. London and New York:Routledge. 